International Journal of Social Sciences and Humanities
Available online at http://sciencescholar.us/journal/index.php/ijssh
Vol. 1 No. 3, December 2017, pages: $17 \sim 27$
e-ISSN: 2550-7001, p-ISSN: 2550-701X
http://dx.doi.org/10.21744/ijssh.v1i3.49

\title{
The Actualization of Cultural Elements in Novel Guru Onyeh by Salman Faris
}

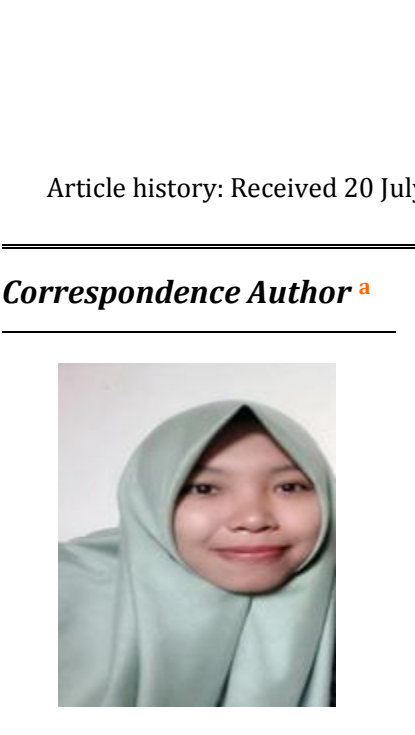

Keywords

Actualization;

Cultural elements;

Literary anthropology;

Guru onyeh;

Sasak community;
CrossMark

\section{Zuhratul Aini ${ }^{a}$} Available online 1 December 2017

\section{Abstract}

Novel with its complexity is a means of self-expression, the contemplation result, observation, imagination, and even the form of social critique of the author. One of the local novels that succeeded in attracting sympathy through the local cultural picture is Salman Faris's novel, Guru Onyeh. Salman Faris is a writer born in Lombok. Salman Faris explores the reality that exists in life of the surrounding community into a literary work in the form of a novel entitled Guru Onyeh. The culture of society explored in this novel is the cultural elements of Sasak people who inhabit the island of Lombok. This novel also discovers the culture of the Sasak community in the reality of life. In order to uncover the actualization of cultural elements in the Sasak society, the novel Guru Onyeh will be studied based on the theory of literary anthropology. This discover the cultural elements contained in the novel and how the actualization of those cultural elements in the novel of Guru Onyeh in the Sasak community is. This study reveals that there are seven elements of culture in the novel Guru Onyeh namely: human life equipment, livelihood, societal system, language, art, knowledge and religion. Each element of the culture still exists in Sasak society.

e-ISSN : 2550-7001, p-ISSN : 2550-701X@ Copyright 2017. The Author. SS Journals Published by Universidad Técnica de Manabí.

This is an open-access article under the CC BY-SA 4.0 license

(https://creativecommons.org/licenses/by-sa/4.0/) All rights reserved.

a Mataram University, Indonesia (ainizuh.332233@gmail.com) 


\section{Contents}

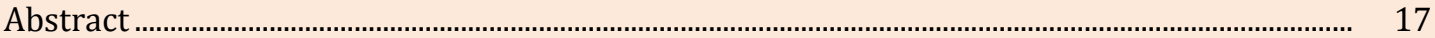

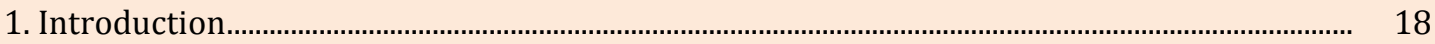

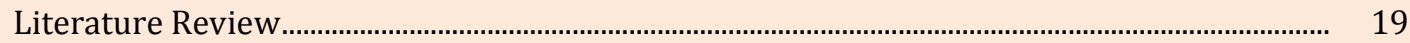

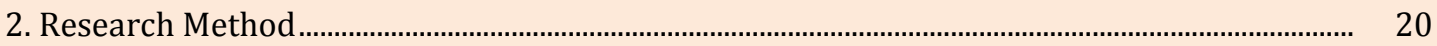

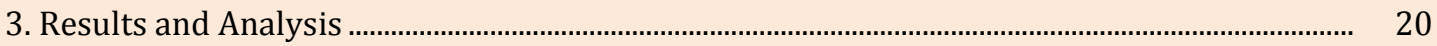

Actualization of the Cultural Elements of the Equipment of Human Life .................................... 20

Actualization of Cultural Elements of Livelihood System ............................................................ 22

Actualization of Cultural System Elements .................................................................................... 23

Actualization of the cultural elements of Language System......................................................... 23

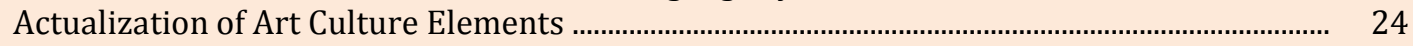

Actualization of the cultural element of Knowledge Systems .................................................... 24

Actualization of Cultural Elements in Religious System .............................................................. 25

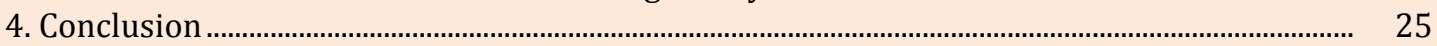

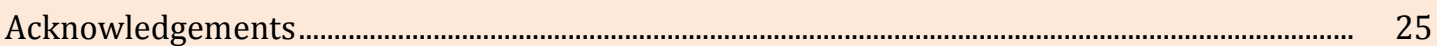

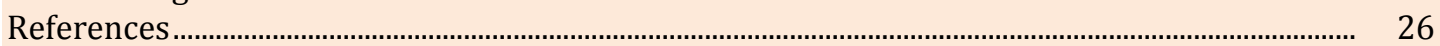

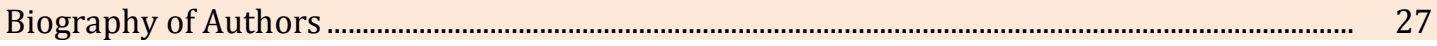

\section{Introduction}

Literature is an alternative to express the phenomenon existing in the reality of people's lives. The phenomenon is employed as an object expressed in the form of literary works such as novels. When a reader enjoys the presentation of the story contained in a novel, he or she is able to know the reality and will get a picture of the phenomenon becoming the object in the story. In this case, literature can be regarded as a reflection of people's lives.

Besides knowing reality and getting a picture of the phenomenon that became the object in the novel, the reader also gains entertainment and can reap useful learning. To be able to reap the meaning and learning, it needs readers' seriousness to explore the literary works (novels) that they read. This is a manifestation of the reader's deeper appreciation concocted by conducting an in-depth review of the literary work. As it is known that novel is a literary work that has a various level of complexity which is different from other literary works.

Novel with its complexity is a means of self-expression, the contemplation result, observation, imagination, and even the form of social critique of the author. A writer mostly expresses ideas in the form of literary works based on the environment in which he or she lives. Residential environment has big influence on the one's literary work. Moreover, literary works (novels) are also deliberately created to introduce the traditions, characteristics, and uniqueness of a community. Therefore, the novel can be categorized as the identity of a certain community that reflects the uniqueness and characteristics differing with other communities.

Salman Faris is one of the authors in Lombok who successfully expresses his ideas in literary works. He is the author who raised the surrounding culture as an object in the literary work of a novel that was created and printed in 2012 entitled Guru Onyeh. Based on the analysis, Novel Guru Onyeh reflects the local wisdom of Sasak people in Lombok Island. The culture explored relates to the problems existing in the real life of Sasak people. Salman Faris through his work depicts the general characteristics of Sasak community. The elements of culture contained in this novel become the main attraction for readers to deeply explore Sasak culture. The literary examination taking the object of cultural element has been done a lot. Nevertheless, it should be admitted that a study focused on cultural elements in the novel is still not widely conducted. The elements of culture used in this study are cultural elements referring to $\mathrm{C}$. Kluckhohn in Kenjoroningrat consisting of 1) equipment of human life; 2) livelihood; 3) community system; 4) language system; 5) the arts; 6) knowledge systems; And 7) religious system. This study will discover the actualization of the cultural elements contained in the novel using the theory of literary anthropology. 
Literature Review

\section{a. Cultural elements}

In order to gain a wider and more detail understanding, referring to C. Kluckhohn, culture is divided into seven types namely (1) the equipment of human life; (2) livelihoods; (3) community system; (4) language (and literary) systems; (5) the arts; (6) knowledge systems; And (7) religious systems.) (Koentjaraningrat in Ratna 2009: 395).

b. Culture

Culture was firstly defined by Taylor in 1871 (in Ratna, 2007: 5) defines that it is the whole of human activity, including knowledge, belief, art, morals, law, customs, and other habits. Sibarani further argues that culture is the whole habits of community groups reflected in science, action, and work as social creatures used to understand the environment and to guide people behaviour to achieve peace and or the welfare of life (Sibarani, 2004: 2).

Sibarani (2004:5) proposes that there are six fundamental things to be considered in defining culture, namely (1) all habits possessed by community habits, (2) knowledge transmitted and socially communicated, (3) reflected and manifested in ideas, (4) guidelines for understanding the human environment and for interacting in the community life, (5) being studied, and (6) prospering and or encouraging the support community.

\section{c. Types of Culture}

According to J.J. Hoenigman (in Koentjoroningrat, 2009: 150) the form of culture is divided into three: ideas, activities, and artefacts. The three types are described as follows.

a. Idea

The ideal form of culture is a culture appeared in form of a group of ideas, opinion, values, norms, rules, and so on that are abstract, intangible or untouched.

\section{b. Activity (action)}

The second form of culture is called social system referring to the patterned actions of the society itself.

\section{c. Artefacts (works)}

An artefact is a form of physical culture resulted from the activities, deeds, and works of all human beings in society in the form of things that can be touched, seen, and documented.

\section{d. Literary Anthropology}

Literary anthropology disputes literary works related to humans as a result of culture. Humans are human beings in the work, especially as personage. In this relation, literature is a multicultural study since through literary works, human diversity with its culture can be well understood (Ratna, 2012: 350).

Endraswara (2015: 1) states that the subject of research in literary anthropology is the attitude and behaviour of human beings through literary and cultural facts. Literary anthropology seeks to study attitudes and behaviours that emerge as a culture in literary works. The task of literary anthropology is to discover the beauty of literary elements built in cultural contexts. It needs to keep in mind that humans are cultured beings who like to think, create, learn, and dynamic -change every time-.

\section{e. Semiotic Cultural}

Semiotics is a cultural semiotic that specifically studies the sign system that is applicable in a particular society culture. It is known that society as a social being has a certain cultural system that has been hereditary maintained and appreciated. The culture within the society that is also the system, uses certain signs that distinguish it from other communities (Pateda, 2010: 30). All ethnic groups in Indonesia have a cultural system that involves processes, activities embodied in a system of signs.

In semiotics, literary texts as the reality faced by reader, it contains communicative potential. The possession of communicative potential is characterized by the use of

Aini, Z. (2017). The actualization of cultural elements in novel Guru Onyeh by Salman Faris. International Journal of Social Sciences and Humanities, 1(3), 17-27. https://doi.org/10.29332/ijssh.v1n3.49 
language symbols in it. However, unlike the symbols used in everyday general communication, the symbol embodied in the literary text is an artistic symbol. When the symbol in daily language is natural, the language in the literary text comes preceded by the subjective motivation of the author so that it is more arbitrary (Aminuddin in Handayani, 2007: 32).

\section{Research Method}

This study will be conducted by employing descriptive approach. Qualitative research is conducted to examine the data related to the existence of cultural elements contained in Salman Faris's novel entitled Guru Onyeh in the form of descriptive data. Then, it is followed by studying the cultural elements contained in the novel Guru Onyeh in real life of Sasak people in Lombok. The next stage is, studying the more dominant elements of culture in Salman Faris's novel Guru Onyeh. In collecting data, this study employed observation and literature method.

Observation is conducted by carefully observing and reading the data to study and to determine. Literature method is done by gathering data in the form of words / phrases / sentences which reflect the form of cultural elements in novel Guru Onyeh by Salman Faris. The method of literature is conducted in this study by using a note technique that records things related to the elements of culture that exist in novel Guru Onyeh. The technique of recording is done to facilitate the data collection in the form of cultural elements contained in Salman Faris's novel by Guru Onyeh by using literary anthropological studies.

\section{Results and Analysis}

Novel Guru Onyeh by Salman Faris is a novel that expresses the elements of Sasak society culture. The cultural elements contained in Guru Onyeh's novel by Salman Faris will be described in terms of the actualization of these cultural elements in the realities of Sasak people's lives. In this case, the reality is related to the real manifestation of various elements of the culture in the life of society. The following is described about the actualization of these cultural elements in the reality of the Sasak people's lives.

\section{a. Actualization of the Cultural Elements of the Equipment of Human Life}

The equipment of human life is one of elements of culture existed in novel Guru Onyeh by Salman Faris. This is manifested in several excerpts found in the novel. The equipment of human life in the novel consists of clothing, food, home and transportation.

In this case, various forms of cultural elements in the form of tools of human life are also presented in the reality of community life. The said community is the tribe of Sasak people who inhabit Lombok Island. Sasak community is an object in Salman Faris's novel Guru Onyeh so that the various elements of the culture is also a description of the reality of life of Sasak community itself. Reality that occurs in the Sasak community proves that the things embodied in the novel is something that has been commonly owned, understood and done by Sasak community as a civilized society. The customs associated with various forms of cultural elements of human life equipment are described as follows.

In terms of clothing, the data found in Guru Onyeh's novel by Salman Faris describes the type of clothing namely Telekung as a prayer outfit, Selendang and Lambung as traditional Sasak clothes worn by women, and Dodot and Sapuk as Sasak custom clothes worn by Men. It means that the reality of Sasak society life still maintains the use of these clothes.

Furthermore, in terms of traditional cloth of Sasak worn by men and women, as mentioned above there are still many uses in the activities of Sasak cultural traditions in Lombok such as in the marriage procession conducted by the Sasak people by applying Sasak custom procession.

The customary women's clothing explored in Guru Onyeh's novel by Salman Faris is Lambung, cloth, scarf and belt. Lambung is a sleeveless custom clothing worn by Sasak women as a shirt (clothing). Lambung is made of plain black fabrics on each edge decorated with gold thread or decoration on the flank of the fabric. The collar on Lambung is shaped like the letter 
"V". The size of Lambung is adjusted to the size of the wearer. Furthermore, subordinate clothing worn by Sasak women is fabric. The fabric used is generally triangular and plaid, but along with the increasing creativity of the community today, many motives are applied not only in the form of triangles and boxes but also other motives. These fabrics are generally used up to the knees or ankles, but most use cloth to the ankles because it looks more polite. Shawls and belts are also included in traditional Sasak clothing. Shawls and belts worn by women Sasak has a similar style, which is a variety of shades for the shawl combined with Anteng motive belt. In order to look neater, hair tied up neatly and can also be bun. However, today more Sasak women wear headscarves. So for the clothes used in the long-sleeved colored leather to cover the arm. As complement, they add jewellery such as bracelets and feet.

Lambung, cloth, belts and scarves are customary clothing that is always a mandatory requirement of women in the implementation of cultural traditions activities in Lombok associated with indigenous Sasak tribe.

Actualizati

In addition, men also have special clothes that are used in every custom occasion. Customs clothing for Sasak men namely Sapuk and Dodot as a mandatory accessory in its involvement in carrying out the cultural traditions of the Sasak in Lombok. Sapuk is headband worn by Sasak men. It is worn in a triangular shape which is then tied behind the head, but there is also a Sapuk that is ready to be worn. If for day-to-day Sasak men worn regular triangular-shaped Sapuk, but for traditional events they wear Sapuk made of Songket. Subsequently, the fabric as a subordinate cloth of Sasak men wear fabric with dangle to ankles. For everyday outfit, Sasak men wear patterned fabrics namely Ragi Genep, while for traditional events they wear various motifs such as Subhanale, puppets etc. Dodot is a kind of cloth as a belt used by Sasak men. Dodot serves as a place to put a dagger, a knife, etc. Motif commonly used for day-to-day is Anteng. For certain custom ceremonies Sasak men wear suits called Pegon.

Thus, it can be said that the actualization of cultural elements in the form of human life equipment manifold clothing is actually found in the Sasak community.

Then, the cultural element of food is also embodied in novel Guru Onyeh. In addition, the cultural element is also actualized in the reality of life of Sasak people. It is realized through the activities of community life that still consume food namely Sambal nyale (sea worm sauce). Sambal nyale is a type of food made from sea worms (nyale) which is believed by the society of Sasak tribe in Lombok as the incarnation of Princess Mandalika. Nyale is usually obtained in a particular season that is in the rainy season based on the calculation of the calendar Sasak that usually coincides with February. It has become a cultural tradition of the Sasak community so it becomes common for them to eat Nyale by being made into a side dish of Sambal Nyale food.

Lumbung is a food storage and symbol of the welfare of Sasak people. The granary is made of woven bamboo and some bamboo pillars as poles. The roof on the hull is shaped like a mountain and swoops down made of weeds. The granary is currently used as a symbol of the Sasak tribe. This is evidenced by the number of government offices using the shape of the roof of the granary as the roof of the front of the building. As presented in the picture below.

Furthermore, the cultural element contained in the novel Guru Onyeh is in the form of human needs on aspects of the board (various buildings, examples of houses or dwellings). Home is a primary human need that is certainly needed as the shelter. As a primary need, as well as a shelter, the house also has a variety of functions that can accommodate other needs of humans who own or inhabit it. Thus, it can be concluded that the house is an important element in the community life, including the community of Sasak in Lombok. It is manifested in the realities of the Sasak community that houses have become one of their priorities in living the individual and collective life systems (family and society). In addition, human needs of the board found in Guru Onyeh's novel are manifested through quotes about the existence of the Musholla as one of the important elements in human life. Musholla is a place used by Moslem as a place of worship, especially for prayer. Its function as a place of worship has been emphasized the importance of the existence of Musholla for the community, especially Sasak

Aini, Z. (2017). The actualization of cultural elements in novel Guru Onyeh by Salman Faris. International Journal of Social Sciences and Humanities, 1(3), 17-27. https://doi.org/10.29332/ijssh.v1n3.49 
people who are Muslims. The real form of it is still found in the middle of the life of the Sasak people. Almost in every region Musholla stands as a place of worship as well as a meeting place between communities

Cultural elements related to the tools of human life are also illustrated in quotations explaining the aspects of transportation. It also became one of the manifestations of human needs, especially the Sasak community as its users are embodied in the novel Guru Onyeh by Salman Faris. In this case, the community's need for transportation means materialized in the type of land transportation such as bicycles, motorcycles and Cidomo. Transportation equipment such as bicycles and motorcycles is a common means of transportation used by people in various regions. However, the means of transportation named Cidomo is one means of transportation that is characterized by culture. The culture is related to the culture owned by the Sasak people in Lombok who use Cidomo as a means of traditional transportation. Cidomo is a means of transportation characterized by the use of animals (horses) as the pullers and it is driven by a coachman from the top of the wagon (coach and passenger seat). Cidomo, as a traditional mass transportation tool in Lombok is still widely used by the Sasak people, especially those living or doing activities in rural areas and areas that are not too far. This proves that in the reality of modern society life, Cidomo is still an important transportation mode choice for Sasak people in Lombok Island.

\section{b. Actalization of Cultural Elements of Livelihood System}

The life of the Sasak community also depends on several activities categorized as a livelihood system. It becomes one of the cultural elements owned by Sasak people in Lombok. The cultural element of the livelihood system is illustrated by several excerpts in Salman Faris's novel Guru Onyeh. As for the reality, Sasak community in Lombok Island has also actualized the elements of the livelihood system in its life. The livelihood system in this case is related to community activities as farmers, teachers, fishermen, farm workers, traders, coachmen, and muly-livelihood. The various livelihoods are described as follows.

As an agrarian area, the Sasak community in Lombok Island has a livelihood system associated with it. It means that some people of the Sasak tribe live through animal husbandry or livestock and agricultural activities. Livestock activities conducted as breeders were scattered almost in the entire island of Lombok. Field farms are also diverse, ranging from raising birds, poultry (chicken, duck), goats, cows, and buffalo to horses. Besides for being sold, animals such as cattle, buffaloes and horses were used as human assistants in other activities, such as rice field hijackers, agricultural commodity carriers, race animals, and Cidomo pullers. All activities related to the field of livestock is done by the community of Sasak people in Lombok from the past until today.

Besides being a rancher or breeder, Sasak people who live in agrarian areas mostly rely on agriculture activities, either as farmers or farm workers. The extent of the island of Lombok that is largely used as a fertile agricultural land make almost part of the Sasak community engaged in agriculture. Sasak people who are involved in agriculture are scattered in almost all areas of Lombok Island, both as farmers and as farm labourers. This condition leads the agricultural field to be regarded as one of important elements in the cultural system which is actualized in life by the Sasak people in Lombok.

Moreover, the rapid development of education in Lombok is also one of variable factors that lead Sasak people to be interested in becoming teachers or educators. The growing number of public and private schools, various students' achievements in Lombok, the development of science and technology, and the existence of some personnel allowances gained by teachers led to the mind-set and career goals of most societies to work as teachers. It also does not become something new in Sasak people life as it can be regarded as part of the cultural element that is owned by the people to this day. Thus, it can be concluded that there has been actualization of livelihoods in the teacher profession in Sasak people life in Lombok.

However, as a dynamic society in the midst of modern life, Sasak people also have multiple livelihoods. This is in accordance with what is described in the excerpt of Salman Faris's novel 
entittled Guru Onyeh. In the reality of life, there are individuals who have multiple livelihoods as their daily activities. For example, a person is a teacher as well as working as a farmer or driver as well as labourers, and so forth. This shows that in reality there has been actualization associated with the multy-livelihoods that exist in the life of the Sasak people).

\section{c. Actualization of Cultural System Elements}

Sasak tribe society is a society that upholds the values and norms in life. The values and norms are contained in various forms of life rules, both written and unwritten. The written and unwritten rules are still adhered to and used as guidelines in living family life, community, culture and religious. It has become an important part that Sasak people know and understand from generation to generation.

In this case, the values and norms held firmly embodied in the cultural element in the form of Sasak community system. So far, there are some values and norms adopted by the Sasak community that manifest into the social system from the past until now in Lombok. Some societal system is engaged with the rules of the visit at night which should not exceed the time limit that has been determined and which is still actualized to date. One element of Sasak society cultures associated with the social system is the element of Sasak nobility that is still exalted and used as a guideline in various behavior of society. In addition, the respected figures such as Tuan Guru. Tuan Guru also become part of the embodiment of community system adopted by the Sasak tribe community to this day. Thus, the values and norms contained in the Sasak community system derived from the ancestors of the Sasak nobility and the Tuan Guru (prominent religious figure) are still the main guidelines in living the life of customs and religion in Lombok.

Moreover, in the social system found in Guru Onyeh by Salman Faris also reveals that the naming of the nobility and society of Sasak usually has a difference. The distinction is an addition to the formal name attached to the first names of the nobles, "Baiq" for women and "Lalu" for men. Until now, the addition of this noble title still appears in the reality Sasak society life. This is the custom of the Sasak nobles who still held firm up to now and always passed down from generation to generation.

\section{d. Actualization of the cultural elements of Language System}

Every society that inhabits a region certainly never be separated from one of the fundamental needs in life that is language. Language is a component that is part of the cultural system owned by a society, including the Sasak tribe community. The language owned and used by the Sasak community in Lombok as a communication tool is called Sasak language.

Sasak language is a language with various dialects that spread almost throughout Lombok Island. These dialects are used by speakers in each region of Lombok Island. The diversity of the dialect shows the existence and wealth possessed by Sasak language as part of the cultural system of the Sasak people in Lombok. In addition, in many dialects are often found and used two main varieties in the community communication system is the variety politeness (ancient) and the variety of impoliteness (generally and widely used).

Sasak community as a society that interact mostly use the local language would have understood the existence and situation of the use of various polite languages and impolite language in the middle of social life. Variety of polite language is usually used on a level that requires communication or interaction that is polite, polite and impressed respect for his opponent. Meanwhile, the variety of impolite language is usually used in a regular or common level by most layers of society at middle and lower levels. It is based on various aspects or factors that support the use of Sasak language with a variety of polite language and rough or popular language in the middle of community life. Thus, it can be said that the society of Sasak tribe on the island of Lombok has actualized the cultural element of the language system in his life.

Aini, Z. (2017). The actualization of cultural elements in novel Guru Onyeh by Salman Faris. International Journal of Social Sciences and Humanities, 1(3), 17-27. https://doi.org/10.29332/ijssh.v1n3.49 


\section{e. Actualization of Art Culture Elements}

The Sasak tribe is a culturally diverse society. It is manifested in one of its life systems that is art system. Art is one of the things that has become part of the life and civilization of the Sasak people who inhabit the island of Lombok. Such a thing has been much evidenced through the historical research on Sasak civilization that has been done since the past.

As a society that has a long civilization in terms of art, the people of Sasak tribe also has various types or forms of art in life. These arts are concrete (cultural attraction) and abstract (written form). The concrete arts include the "Nyongkolan" traditions, "Jangger" dance, "Wayang Sasak" show, "Gendang Beleq" art, and various types of traditional games. Meanwhile, art that is abstract includes folklore and traditional songs.

In this case, the tradition of Nyongkolan and Gendang beleq is one-unit in terms of the actualization in Sasak society. This is because both things are done usually at a wedding momentum that uses the custom of the Sasak. Unravelling itself is generally understood as a cultural attraction owned and conducted by the Sasak community in order to deliver the bride by the bridegroom after the wedding procession is held with the procedure that is walking to the bride's residence accompanied by many accompaniments, one of them is also the players of Gendang Beleq. This tradition is still maintained and actualized by Sasak community in almost all areas of Lombok. As shown in the picture below.

Furthermore, two other things are also usually appear in a package is a Wayang Sasak show accompanied by attractions namely "Jangger" traditional dance of Sasak. At this time, Wayang Sasak show has begun to get priority places from the public and the government so it is almost always popular and crowded when the show is held, especially if it is coupled with Jangger that becomes additional entertainment for the community. Jangger itself is generally played on the events or entertainment activities before or after the wedding or other traditional activities in the community by dancing Jangger accompanied by traditional music Sasak and traditional songs that the time of its execution is usually from evening until dawn. Such attractions are still widely found in the lives of Sasak people to this day.

Other arts activities that are also an important part in the development of Sasak civilization is literature art owned by the Sasak community. This is evidenced by the results of the previous article such as Babad Sakra, Babad Praya, Babad Pejanggik, Babad Selaparang still exist. The Lontar manuscripts contain much of the history of the earlier development of the kingdom which is packed with interesting by the writers. This is done so that the future generations do not forget the history of some kingdom that ever existed and controlled some areas in Lombok. Until now the existence of Lontar manuscripts are still widely found in the midst of society or in the mudium.

One of elements of culture that cannot be separated from art is Songket. Sasak people have a work of art namely Songket. Today, the actualization of it is still awake. This is evidenced by the large number of Sasak people who wear Songket cloth in certain events. Even in some events Songket is one of the clothes that must be worn by the Sasak community.

\section{f. Actualization of the cultural element of Knowledge Systems}

One of the cultural elements possessed by the Sasak people is the knowledge system. It is contained in several excerpts in Guru Onyeh's novel by Salman Faris. The system of knowledge is related to various understanding and intellectual ability possessed by society of Sasak tribe from ancient times until today.

The understanding and intellectual ability is related to the development of public knowledge about various things that exist in this world, especially related to general science. It is actualized through various forms of intellectual activity (education) and knowledge system in the life of the Sasak people. The intellectual activity is related to the knowledge of the Sasak people to the geographical boundaries of Lombok Island, the number and name of the tribe that inhabited the island of Lombok and to matters related to other general knowledge. 


\section{g. Actualization of Cultural Elements in Religious System}

Sasak people life in Lombok Island is inseparable from one of the elements of culture that is religious life or religious system. The religious system of the Sasak people has evolved since ancient with the discovery of various historical evidence about religious life in Lombok Island. The period of development of religious life experienced by the Sasak people in Lombok lasts very long. This has been mentioned in various historical writings on religious developments in Lombok, both related to the religious conditions of Hindu-Buddhist background, animism beliefs to the arrival of Islam that widely spread widely and embraced by most Sasak tribe society to date. Whereas, related to the history of the development of Islamic life of the Sasak society, it will take a long time to describe it because the process of religious life based on Islam in Lombok lasted for a very long time.

In the realities of the Sasak people living in Lombok, the various things mentioned above have been widely actualized both individually and collectively and carried out at times that have also been determined. This is because almost all Sasak people in Lombok embraced the teachings of Islam with the same concept of religiosity so that these things can continue to take place in the middle of community life.

\section{Conclusion}

There are seven cultural elements explored in Guru Onyeh's novel by Salman Faris. The seven elements of the culture are 1) the equipment of human life in the form of clothing, food, home, and transportation, 2) livelihoods in the form of shepherd, farming, teacher, fisherman, coachman and multy-livelihood, 3) The rules that exist in Sasak society still held firm by the community, 4) language system in the form of language used by the Sasak people in daily life that is Sasak language, 5) art consisting of dance, drama, music, literature , And fine arts, 6) knowledge in the form of knowledge about the Sasak region and the natural beauty that is in it and 7) religious system in the form of Sasak people's belief that is still held firm by the people. The actualization of the cultural elements found in Guru Onyeh's novel by Salman Faris is still visible in the daily life of the Sasak people).

\section{Acknowledgement}

Thank you so much for my father and mother Muhdar and Muspiani who have given everything to me and sacrificed his fatigue for my happiness and success. Furthermore, I also thank to Khairil Anwar who always provide motivation, understanding and attention so far.

Aini, Z. (2017). The actualization of cultural elements in novel Guru Onyeh by Salman Faris. International Journal of Social Sciences and Humanities, 1(3), 17-27. https://doi.org/10.29332/ijssh.v1n3.49 


\section{References}

Arikunto, S. (2006). Research Procedure A Practical Approach. Jakarta: Rineka Cipta. View in (Google Scholar)

Astawa, I. N., Mantra, I. B. N., \& Widiastuti, I. A. M. S. (2017). Developing Communicative English Language Tests for Tourism Vocational High School Students. International Journal of Social Sciences and Humanities (IJSSH), 1(2), 58-64. View in (Google Scholar)

Basak, A., \& Khanna, K. (2017). A Study on the Selection Criteria of Different Hotels of Delhi NCR in Accordance to the HR Policies and Market Trends. International Journal of Social Sciences and Humanities (IJSSH), 1(1), 27-38. View in (Google Scholar)

Billaiya, R., Malaiya, S., \& Parihar, K. S. (2017). Impact of Socio Economic Trends on Students in Quality Education System. International Journal of Social Sciences and Humanities (IJSSH), 1(1), 16-20. View in (Google Scholar)

Cedeño, M. L. D., Arteaga, M. G. D., Pérez, A. V., \& Arteaga, M. L. D. (2017). Regulatory Framework for Renewable Energy Sources in Ecuador Case Study Province of Manabí. International Journal of Social Sciences and Humanities (IJSSH), 1(2), 29-42. View in (Google Scholar)

Christomy, T. (2013). Signs of Wali: Narratives at the Sacred Sites in Pamijahan, West Java (p. 221). ANU Press. View in (Google Scholar)

Emzir, dan Saiful Rohman. 2015. Theory and Literature Teaching. Jakarta: Rajawali Press. View in (Google Scholar)

Endraswara, S. (2015). Kajian Budaya Religi dan Ritual. Studi Religi dan Ritual Antro, Teguh Imam Prasetyo (ed). Accesses, 21. View in (Google Scholar)

Faris, Salman. 2012. Guru Onyeh Adventures in Gumi Paer. Lombok: STKIP Hamzanwadi Press dan Leppim IAIN Mataram. View in (Google Scholar)

Hoed, Benny H. 2014. Semiotics and Social Cultural Dynamics. Depok: Komunitas Bambu. View in (Google Scholar)

Huitt, W. (1997). Metacognition. Educational Psychology Interactive. Valdosta, GA: Valdosta State University. View in (Google Scholar)

Koentjaraningrat. 2009. Introduction to Anthropology. Jakarta: Rineka Cipta. View in (Google Scholar)

Maba, W. (2017). Teacher's Perception on the Implementation of the Assessment Process in 2013 Curriculum. International Journal of Social Sciences and Humanities (IJSSH), 1(2), 1-9. View in (Google Scholar)

Moleong, Lexi J. 2013. Qualitative Research Methodology Revised Edition.Bandung: Remaja Rosdakarya. View in (Google Scholar)

Nurgiyantoro, Burhan. 2012. Theory of Fictional Assessment. Yogyakarta: Gadjah Mada University Press. View in (Google Scholar)

Pateda, Mansoer. 2010. Semantic Lexical. Jakarta: Rineka Cipta. View in (Google Scholar)

Pradopo, Rachmat Djoko dkk. 2001. Research Methodology Literature. Yogyakarta: Hanindita Graha Widya. View in (Google Scholar)

Ratna, Nyoman Kutha. 2007. Literature and Cultural Studies Fiction and Fact Representation. Pustaka Pelajar: Yogyakarta. View in (Google Scholar)

Ratna, Nyoman Kutha. 2011. Literary Anthropology The Role of Cultural Elements in the Creative Process. Pustaka Pelajar: Yogyakarta. View in (Google Scholar)

Ratna, Nyoman Kutha. 2012. Theory, Methods, and Techniques of Literary Research. Pustaka Pelajar: Yogyakarta. View in (Google Scholar)

Semi, Atar. 1990. Research Methods Literature. Bandung: Angkasa Bandung. View in (Google Scholar)

Sibarani, R. (2015). Pendekatan Antropolinguistik terhadap Kajian Tradisi Lisan. RETORIKA: Jurnal Ilmu Bahasa, 1(1), 1-17. View in (Google Scholar)

Stanton, Robert. 2012. Feminist theory: The intellectual traditions. Bloomsbury Publishing USA. View in (Scopus) 
Suparsa, I. N., Mantra, I. B. N., \& Widiastuti, I. A. M. S. (2017). Developing Learning Methods of Indonesian as a Foreign Language. International Journal of Social Sciences and Humanities (IJSSH), 1(2), 51-57. View in (Google Scholar)

Suryasa, I. W., Prayoga, I. G. P. A., \& Werdistira, I. W. A. (2017). An Analysis of Students' Motivation Toward English Learning As Second Language Among Students In Pritchard English Academy (PEACE). International Journal of Social Sciences and Humanities (IJSSH), 1(2), 43-50. View in (Google Scholar)

Thwaites, T., Davis, L., \& Mules, W. (2002). Introducing cultural and media studies: a semiotic approach. Palgrave. View in (Scopus)

Biography of Author

\begin{tabular}{|l|l||}
\hline \hline Zuhratul Aini was born in in 1992 in Apitaik, Pringgabaya, East \\
Lombok. Currently, she is a student of Bahasa Indonesia education \\
program at school of postgraduate study, Mataram University. She got \\
her bachelor degree majoring Pendidikan Bahasa Indonesia at \\
Mataram University and during that time she was active in Teater \\
Putih, one of students' organisation in Faculty of Teacher Training and \\
Education, Mataram Univesrity. Currently, besides being a graduate \\
student, she also contributes and serves as a teacher in SMPN 3 \\
Pringgabaya.
\end{tabular}

Aini, Z. (2017). The actualization of cultural elements in novel Guru Onyeh by Salman Faris. International Journal of Social Sciences and Humanities, 1(3), 17-27. https://doi.org/10.29332/ijssh.v1n3.49 